\title{
Keputusan afiliasi OTA dan kinerja Hotel: Studi Pada Hotel Berafiliasi
}

\author{
${ }^{1)}$ Antonius Singgih Setiawan \\ ${ }^{2)}$ Lina \\ 1,2) Fakultas Bisnis Akuntansi Universitas Katolik Musi Charitas \\ Korespondensi: singgih@ukmc.ac.id
}

\begin{abstract}
At present, the hotel industry is at a very dynamic level of competition. The intense competition requires hotel managament to implement the right strategy. One strategy that must be implemented is a digital marketing strategy. Digital marketing strategy is a choice of strategies that are developing at this time. However, the development of hotel marketing practices through digital marketing has not been much followed by research developments in the field of digital marketing in the hotel industry. Therefore, this study aims to prove whether the hotel's decision to implement a digital marketing strategy by affiliating with an online travel agent (OTA) will achieve better performance. The research uses exploratory quantitative methods. The data is processed using descriptive statistics, using data collected from 65 respondents who are hotel owners/managers. The results showed that the hotel decision affiliated with OTA had a positive impact on hotel performance.
\end{abstract}

Keywords: digital marketing strategy; online travel agent; hotels performance.

\section{Pendahuluan}

Beberapa tahun terakhir ini, wilayah Sumatera Selatan mengalami pertumbuhan industri hotel yang relatif pesat (Setiawan et al., 2019a). Pertumbahan dan perkembangan industri perhotelan di wilayah Sumatera telah mengarah pada persaingan yang dinamis dan ketat (Setiawan et al., 2019b). Selain itu, industri hotel dikenal memiliki karakteristik unik yang berbeda dengan industri pada umumnya. Investasi industri hotel dicirikan sebagai bisnis yang berisiko tinggi, karena tamu hotel digambarkan sebagai penyewa kamar yang hanya beberapa hari atau bahkan hanya sehari sehingga tingkat perputaran pelanggan adalah salah satu aspek utama yang harus dikelola (Jeffrey et al., 2002). Oleh karena itu, diferensiasi kualitas layanan menjadi penting karena akan berhubungan dengan struktur biaya dan akhirnya mempengaruhi perbedaan kepuasan pelanggan sesuai dengan kompleksitas dari kepuasan permintaan pelanggan (Younes \& Kett, 2007).

Industri hotel juga merupakan industri yang menyediakan jasa kepuasan yang lebih bersifat private dan personal. Industri hotel sering kali juga berhubungan dengan industri yang menyediakan kepuasan gaya hidup bagi pelanggannya. Oleh sebab itu, pasar hotel juga ditandai dengan segmentasi permintaan yang kuat yang berkaitan dengan potensi ekspektasi tamu (Baum \& Haveman, 1997). Hal itu menunjukkan bahwa industri hotel adalah industri jasa yang sensitif karena akan secara langsung berhubungan dengan kepuasan individu pengguna jasa pada saat jasa diterima. Tingkat perputaran tamu hotel yang cepat menjadi kunci keberhasilan kinerja hotel. Oleh karena itu, persaingan menjadi tantangan yang hars dihadapi oleh setiap pengelola hotel, dan tingkat persaingan yang 
semakin ketat menuntut pengelola hotel menerapkan strategi yang tepat untuk mendapatkan kinerja yang optimal (Setiawan, 2016). Strategi yang saat ini banyak dipilih adalah strategi pemasaran digital.

Metode pemasanan digital yang saat ini berkembang adalah pemasaran hotel secara online, termasuk di dalamnya adalah situs web hotel dan situs web online travel agent (OTA) (Liu \& Zhang, 2014). Penggunaan situs bisnis pemasaran hotel telah menjadi kebutuhan dan tuntutan bagi pengelola hotel untuk memperkuat hubungan dengan pelanggan, dan untuk memperlebar segmen pasar (Law et al., 2010). Untuk itu, pengelola hotel harus mencantumkan informasi pemasaran hotel melalui web OTA (Pan et al., 2013). Perkembangan praktik pemasaran hotel melalui digital marketing ternyata belum banyak diikuti oleh perkembangan penelitian di bidang tersebut di industri hotel. Hal ini seperti dijelaskan oleh Melo et al. (2017) yang menyatakan literatur dan penelitian mengenai digital marketing dan kinerja pada industri hotel belum mendapatkan porsi yang besar. Oleh sebab itu, penelitian ini akan melihat keputusan pemilik/manajemen hotel dalam membuat keputusan untuk memasarkan hotelnya melalui situs OTA apakah akan berdampak pada kinerja hotel.

\section{Hubungan implementasi digital marketing dan kinerja hotel}

Law et al. (2010) menjelaskan bahwa hotel yang berorientasi pada pelanggan telah semakin mengadopsi model e-bisnis. Saat ini, para tamu hotel lebih suka memesan hotel melalui pemesanan online (Liu \& Zhang, 2014). Sebagai dampak dari implementasi pemasaran kreatif hotel tersebut adalah pencapaian kinerja hotel yang lebih baik (Sigala dan Chalkiti, 2015). Hal ini juga didukung oleh Yfantidou et al. (2019) yang menjelaskan bahwa inovasi dan kreatifitas yang dijalankan oleh pengelola hotel akan berdampak pada peningkatan kinerja hotel.

Sainaghi (2010) merumuskan kinerja hotel kedalam tiga katagori utama, yaitu: pertama, kinerja yang behubungan dengan aktivitas operasional hotel yang meliputi occupancy, kepuasan yang dapat dirasakan oleh setiap tamu hotel dan orientasi pada kulaitas jasa hotel yang disediakan. Kedua, kombinasi antara kinerja operasional hotel dan keuangan hotel yang meliputi profitabilitas keuangan dan volume penjulan, profitabilitas keuangan dan kualitas jasa, serta kombinasi antara profitabilitas keuangan, volume penjualan, dan kepusan pelanggan. Ketiga, lebih berfokus pada kinerja keuangan yang meliputi rasio-rasio keuangan dan marjin keuangan.

Beberapa temuan penelitian telah mengidikasikan hubungan positif antara implementasi inovasi digital marketing hotel dan kinerja hotel. Kang et al. (2014) menemukan fakta bahwa strategi pemasaran kreatif memiliki dampak positif pada kinerja hotel. Pelsmacker et al. (2018) menyimpulkan bahwa implementasi strategi pemasaran digital membawa dampak positif pada kinerja hotel. Blal et al. (2018) juga menyimpulkan bahwa hotel-hotel yang berafiliasi dengan OTA memiliki kinerja yang lebih baik dari pada yang tidak berafiliasi. Berdasarkan beberapa uraian literatur tersebut maka, penelitian ini perlu membuktikan apakah hotel-hotel di kota Palembang yang memutuskan berafiliasi dengan OTA memiliki kinerja yang lebih baik. 


\section{Metode penelitian}

Penelitian ini merupakan penelitian eksplorasi. Pengumpulan data penelitian menggunakan teknik survei. Data penelitian dikumpulkan menggunakan kuesioner dengan responden pemilik/pengelola hotel yang berafiliasi dengan OTA OYO di Palembang. Survei ditujukan kepada 75 hotel, namun demikian data yang dapat diolah sebanyak 65 kuesioner dengan tingkat pengembalian 87\%. Kinerja hotel diukur menggunakan instrumen (Pelsmacker et al., 2018). Responden diminta untuk mengidentifikasi kinerja hotel apakah meningkat atau menurun berdasarkan ekspektasi setelah memutuskan berafiliasi dengan program pemasaran OTA OYO. Tiga item indikator tersebut yaitu, pendapatan penjualan, tingkat occupancy dan laba operasi. Jawaban menggunakan skala 6 point $(1=$ Jauh di bawah perkiraan, $6=$ jauh diatas perkiraan). Data yang terkumpul diolah mengunakan statistik deskriptif untuk mengetahui persepsi responden terhadap tingkat kinerja hotel setelah berafiliasi dengan OTA OYO untuk selanjutnya dianalisis untuk mendapatkan kesimpulan atas masalah yang diteliti.

\section{Hasil penelitian}

Tabel 1. Data Demografi Responden/Hotel

\begin{tabular}{ccc}
\hline Profil Responden & Jumlah & $(\boldsymbol{\%})$ \\
\hline 1. Jenis Kelamin & & 33,8 \\
Perempuan & 22 & 66,2 \\
Laki-laki & 43 & \\
2. Pendidikan Terakhir & & 15,4 \\
Diploma & 10 & 66,2 \\
S1 & 43 & 1,5 \\
S2 & 2 & 0 \\
S3 & 0 & 16,9 \\
Lainnya & 11 &
\end{tabular}

Sumber: Data diolah tahun 2020

Berdasarkan Tabel 1, responden yang berpartisipasi dalam penelitian sebanyak 65 orang pemilik/pengelola hotel mitra OYO di kota Palembang. Berdasarkan jenis kelamin, responden perempuan berjumlah 22 orang $(33,8 \%)$, responden laki-laki berjumlah 43 orang $(66,2 \%)$. Tingkat pendidikan responden yang berpartisipasi dalam penelitian ini adalah, 10 orang $(15,4 \%)$ memiliki pendidikan akhir diploma, 43 orang $(66,2 \%)$ berpendidikan S1, 1 orang $(1,5 \%)$ berpendidkan S2, dan sisanya 11 orang $(16,9 \%)$ menyebutkan lainnya.

Tabel. 2 Usia Responden

\begin{tabular}{cccc}
\hline Profil Responden & Termuda & Tertua & Rata-rata \\
\hline Usia & 27 & 58 & 43,15 \\
Jumlah kamar & Paling sedikit & Paling banyak & \\
\hline
\end{tabular}

Sumber: Data diolah tahun 2020

Tabel 2 menunjukkan tingkat usia responden. Tingkat usia responden berada pada kisaran 27 hingga 58 tahun dengan rata-rata usia adalah 43,15 tahun. Berdasarkan jumlah kamar yang dioperasikan oleh hotel, jumlah kamar paling sedikit dimiliki hotel adalah sebanyak 7 
kamar, sedangan jumlah kamar paling banyak adalah 93 kamar dengan rata-rata 28,37 kamar.

Tabel 3. Kinerja hotel setelah berafiliasi dengan OTA OYO

\begin{tabular}{lcccc}
\hline \multicolumn{1}{c}{ Indiator } & $\begin{array}{c}\text { Kisaran } \\
\text { Teoritis }\end{array}$ & $\begin{array}{c}\text { Kisaran } \\
\text { aktual }\end{array}$ & Mean & Standar Deviasi \\
\hline Pendapatan Penjualan & $1-6$ & $3-6$ & 4,55 & 0,73 \\
Tingat Occupancy & $1-6$ & $3-6$ & 4,71 & 0,84 \\
Laba Operasi & $1-6$ & $3-6$ & 4,75 & 0,87 \\
Total Kinerja Hotel & $3-18$ & $9-17$ & 14,02 & 2,073 \\
\hline
\end{tabular}

Sumber: Data diolah tahun 2020

Tabel 3 menunjukkan data kinerja hotel mitra OYO berdasarkan persepsi para pemilik/pengelola hotel pasca berafiliasi dengan OTA OYO. Indikator kinerja dilihat berdasarkan 3 ukuran utama kinerja hotel yaitu, pendapatan penjualan, tingkat occupancy, dan laba operasi hotel. Namun demikian, penelitian ini juga menunjukkan data persepsi kinerja hotel secara total untuk memberikan gambaran secara umum kinerja hotel setelah berafiliasi dengan OTA OYO.

Berdasarkan persepsi para pemilik dan pengelola hotel yang telah berafiliasi dengan OTA OYO. Responden penelitian memberikan keyakinan bahwa pencapaian kinerja hotel berdasarkan tingkat pendapatan penjualan setelah berafiliasi dengan OTA OYO ternyata melebihi ekspektasi mereka sebelumnya. Hal ini ditunjukan berdasarkan data rata-rata persepsi apakah tingkat pendapatan penjualan meningkat melebihi ekspektasi responden setelah berafiliasi dengan OTA OYO berada pada angka rata-rata 4,55 dengan kisaran teoritis $1-6$, dan kisaran aktual $3-6$. Hal ini dapat mengindikasikan bahwa, hotel yang telah bergabung dalam digital marketing OTA OYO telah mendapatkan manfaat positif dalam mencapai kinerja pendapatan penjualan.

Tabel 3 juga menunjukkan data responden penelitian yang memberikan keyakinan bahwa pencapaian kinerja hotel berdasarkan tingkat occupancy juga meningkat berdasarkan ekspektasi saat pemilik/pengelola hotel belum berafiliasi dengan OTA OYO. Data rata-rata persepsi apakah tingkat tingkat ocupancy hotel meningkat setelah berafiliasi dengan OTA OYO berada pada angka rata-rata 4,71 dengan kisaran teoritis $1-6$, dan kisaran aktual $3-6$. Hal ini dapat mengindikasikan bahwa, hotel yang telah bergabung dalam digital marketing OTA OYO telah mendapatkan manfaat positif dari peningkatan tingkat occupancy hotel.

Hasil penelitian juga menunjukkan fakta empiris bahwa keyakinan pemilik/pengelola hotel terhadap kinerja hotel berdasarkan laba operasi juga meningkat setelah berafiliasi dengan OTA OYO. Data rata-rata persepsi apakah tingkat laba operasi hotel meningkat melebihi ekspektasi responden setelah berafiliasi dengan OTA OYO berada pada angka rata-rata 4,75 dengan kisaran teoritis $1-6$, dan kisaran aktual $3-6$. Hal ini dapat mengindikasikan bahwa, hotel yang telah bergabung dalam digital marketing OTA OYO telah mendapatkan manfaat positif peningkatan laba operasi hotel.

Akhirnya, berdasarkan total skor persepsi pemilik/pengelola hotel terhadap pencapaian kinerja hotel setelah berafiliasi dengan OTA OYO, kinerja hotel mitra OYO di kota Palembang berada pada rata-rata 14,02 dengan kisaran teoritis antara 3 - 18 dan 
kisaran aktual antara $9-17$. Data ini memberikan gambaran secara umum bahwa kinerja hotel yang berada di wilayah kota Palembang dan yang telah berafiliasi dengan OTA OYO memiliki kinerja yang relatif tinggi.

\section{Pembahasan}

Temuan empiris dari penelitian ini memberikan tambahan informasi penting bahwa implementasi strategi kreatif dalam pengelolaan industri hotel dapat berperan dalam mendukung pencapaian kinerja hotel. Temuan penelitian secara umum mampu menegaskan bahwa terdapat hubungan positif antara penerapan digital marketing melalui afiliasi hotel dengan OTA dan pencapaian kinerja hotel. Tiga indikator kinerja yang diidentifikasi untuk menunjukkan kinerja hotel berhasil memberikan gambaran pengaruh positif dari penerapan strategi kreatif tersebut.

Pencapaian pendapatan penjualan hotel yang melebihi ekspektasi pemilik/pengelola hotel menunjukkan bahwa keputusan untuk berafiliasi dengan OTA merupakan keputusan yang tepat. Hal ini sesuai dengan hasil penelitian sebelumnya yang dilakukan oleh Kang et al. (2014) bahwa strategi aliansi pemasaran kreatif berdampak positif terhadap kinerja hotel. Hal ini juga sesuai dengan temuan Lien et al. (2015) bahwa saat ini para wisatawan lebih memilih memesan hotel dan penginapan melalui jaringan online.

Peningkatan pencapaian pendapatan penjualan hotel juga terdukung oleh data empiris mengenai peningkatan tingkat occupancy hotel pasca berafiliasi dengan OTA OYO. Semakin banyak kamar hotel yang terisi maka akan berdampak positif terhadap peningkatan pendapatan hotel. Temuan ini juga memperjelas paradigma pengukuran kinerja terintegrasi bahwa, keberhasilan pencapaian kinerja keuangan tidak dapat dilepaskan dengan keberhasilan dalam penecapaian kinerja nonkeuangan. Hal lain yang membuktikan adalah, temuan penelitian juga mengindikasikan bahwa pencapaian kinerja laba operasi mengalami pencapaian yeng lebih baik setelah pemilik/pengelola hotel memutuskan untuk berafiliasi dengan OTA OYO. Tingkat occupancy yang meningkat dan diikuti dengan peningkatan pendapatan penjualan, maka menjadi wajar jika laba operasi hotel ikut meningkat.

Oleh sebab itu, hasil penelitian ini mengkonfirmasi Sainaghi (2010) bahwa kinerja terintegrasi hotel dapat dilihat berdasarkan ketiga indikator tersebut, yaitu pendapatan penjualan, tingkat occupancy dan laba operasi. Hasil penelitian juga semakin menguatkan beberapa literatur sebelumnya bahwa, pilihan strategi yang tepat akan membawa perusahaan pada pencapaian kinerja yang semakin meningkat (Lee \& Yang, 2011; McManus, 2013; Mia \& Winata, 2014; Su et al., 2015).

\section{Kesimpulan}

Sebagai bagian akhir dari penelitian ini, hasil penelitian memberikan kesimpulan sebagai berikut, keputusan pemilik/pengelola hotel berafiliasi dengan OTA merupakan pilihan strategi yang tepat untuk diimplementasikan saat ini. Terlebih, saat ini industri hotel telah berada pada kondisi persaingan yang sangat dinamis. Oleh sebab itu, perkembangan 
teknologi informasi yang berdampak pada inovasi pemasaran berbasis digital marketing harus direspon cepat oleh para pemilik dan pengelola hotel.

Penelitian menghasilkan kesimpulan temuan bahwa terdapat dampak positif dari keputusan pemilik/pengelola hotel di kota Palembang untuk berafiliasi dengan OTA OYO. Kinerja hotel dalam indikator pendapatan penjualan, tingkat occupancy, dan laba operasi dipersepsikan oleh para pemilik/pengelola hotel dicapai meningkat melampaui ekspektasi mereka sebagai dampak dari keputusan berafiliasi dengan OTA OYO.

Berdasarkan hasil penelitian ini, implikasi penting yang perlu dipertimbangkan bagi para pemilik/pengelola hotel yang belum memutuskan untuk berafiliasi dengan OTA, mereka harus segera mengambil keputusan untuk berafiliasi dengan OTA atau setidaknya memanfaatkan strategi digital marketing dalam mengembangkan bisnis hotel mereka. Hal ini telah terbukti bahwa dengan memanfaatkan digital marketing, hotel dapat memperluas jangkauan pemasaran dan dapat mempertajam segmen pasar yang mereka kehendaki.

Namun demikian, penelitian ini masih memiliki beberapa keterbatasan. Penelitian ini hanya dilakukan menggunakan metode serderhana kuantitatif deskriptif. Penelitian selanjutnya disarankan untuk mengidentifikasi faktor-faktor penting yang dimungkinkan menjadi dasar alasan mengapa pemilik/pengelola hotel membuat keputusan untuk berafiliasi dengan OTA. Perlu juga untuk menguji beberapa faktor yang berkemungkinan menjadi pengaruh kunci dari keberhasilan keputusan afiliasi sebuah hotel dengan OTA. Beberapa faktor tersebut misalnya, sifat kerjasama. Sifat kerja sama dapat dilihat dalam dua alternatif, yaitu apakah dalam bentuk kemitraan atau pengelolaan penuh oleh operator. Selain itu, penelitian juga bisa mengidentifikasi tentang durasi kerjasama. Durasi kerjasama bisa dilihat dalam pilihan jangka pendek, jangka menegah atau jangka panjang. Beberapa faktor tersebut didasarkan pada literatur hubungan strategi outsourcing dan keberhasilan strategi outsoucing (Setiawan, 2008).

\section{Daftar Pustaka}

Baum, J. A. C., \& Haveman, H. A. (1997). Love the neighbor differentiation and agglomeration in the Manhattan hotel industry 1898-1990. Administrative Science Quarterly, 42(2), $304-338$.

Blal, I., Singal, M., \& Templin, J. (2018). Airbnb's effect on hotel sales growth. International Journal of Hospitality Management, 73, 85 - 92.

Jeffrey, D., Barden, R. R. D., Buckley, P. J., \& Hubbard, N. J. (2002). What makes for a successful hotel? Insights on hotel management following 15 years of hotel occupancy analysis in England. Service Industries Journal, 22(2), 73 - 88.

Kang, S., Hur, W. M., \& Kim, M. (2014). The mediating role of alliance marketing program creativity on the relationship between alliance orientation and market performance in the services industry. Managing Service Quality, 24(5), 522 - 540.

Law, R., Qi, S., \& Buhalis, D. (2010). Progress in tourism management: A review of website evaluation in tourism research. Tourism Management, 31(3), 297 - 313.

Lee, C. L., \& Yang, H. J. (2011). Organization structure, competition and performance measurement system and their joint effect on performance. Management Accounting Research, 22(2), $84-104$. 
Lien, C. H., Wen, M. J., Huang, L. C., \& Wu, K. L. (2015). Online hotel booking: The effects of brand image, price, trust and value on purchase intentions. Asia Pacific Management Review, 20(4), 210 - 218.

Liu. J. N. K., \& Zhang. E. Y. (2014). An investigation of factors affecting customer selection of online hotelbooking channels. International Journal of Hospitality Management, 39, $71-83$.

McManus, L. (2013). Customer accounting and marketing performance measures in the hotel industry: Evidence from Australia. International Journal of Hospitality Management, 33(1), 140 - 152.

Melo, A. J., Hernández-Maestro, R. M., \& Muñoz-Gallego, P. A. (2017). Service quality perceptions, online visibility, and business performance in rural lodging establishments. Journal of Travel Research, 56(2), 250 - 262.

Mia, L. \& Winata, L. (2014). Manufacturing strategy and organisational performance: The role of competition and MAS information. Journal of Accounting \& Organizational Change, 10(1), $83-115$.

Pan, B., Zhang, L., \& Law, R. (2013). The complex matter of online hotel choice. Cornell Hospitality Quarterly, 54 (1), $74-83$.

Pelsmacker. P. D., Tilburg, S., \& Holthof. C. (2018). Digital marketing strategies, online reviews and hotel performance. International Journal of Hospitality Management, $72,47-55$.

Sainaghi, R. (2010). Hotel performance: "state of the art". International Journal of Contemporary Hospitality Management, 22(7), 920 - 952.

Setiawan, A. S. (2008). Hubungan strategi outsourcing information technology dan keberhasilan outsourcing information technology (Studi empiris pada perusahaanperusahaan yang terdaftar di BEJ). Jurnal Akuntansi, 12(2), 189 - 206.

Setiawan, A. S. (2016). Pengaruh pemilihan strategi deferensiasi terhadap kinerja keuangan (Studi empiris pada perusahaan manufaktur food \& beverages terdaftar di BEI). Jurnal Akuntansi, 20(1), $104-116$.

Setiawan, A. S., Rahmawati., Djuminah., \& Widagdo, A. K. (2019a). The impact of business strategy formulation towards acountant role: Star rating as moderating variable in hotel industry in Southern Sumatera Region. International Journal of Enggineering and Technology, 11(4), 749 - 755.

Setiawan, A. S., Rahmawati., Djuminah., Widagdo, A. K. (2019b). Owner power, deliberate strategy formulation, and strategic management acounting. Opcion, 35(89), $254-270$.

Sigala, M., \& Chalkiti, K. (2015). Knowledge management, social media and employee creativity. International Journal of Hospitality Management, 45(1), 44 - 58.

Su, S., Baird, K., \& Schoch, H. (2015). The moderating effect of organisational life cycle stages on the association between the interactive and diagnostic approches to using control with organisational performance. Management Accounting Research, 26(1), $40-53$.

Yfantidou, G., Spyridopoulou, E., Chatzigeorgiou, T., \& Malliou, P. (2019). Hotel innovation and the creation of competitive advantage. In Katsoni, V \& Segarra-Ona M (Eds.). Smart tourism as a driver for culture and sustainability. Springer proceedings in business and economics, $135-144$.

Younes, E., \& Kett, R. 2007. Hotel investment risk? What are the chances? Journal of Retail and Leisure Property, 6(1), 69 - 78. 